\title{
Pengaruh integrasi, berbagi informasi, dan penundaan pada kinerja rantai pasokan: Studi pada usaha kecil menengah batik di Indonesia
}

\author{
Ihwan Addin Mufaqih ${ }^{1}$, Nurul Indarti2 ${ }^{*}$, Wakhid S. Ciptono ${ }^{3}$, Any Kartikasari ${ }^{4}$ \\ ${ }^{1,2,3}$ Departemen Manajemen, Fakultas Ekonomika dan Bisnis Universitas Gadjah Mada \\ ${ }^{4}$ Fakultas Matematika dan Ilmu Pengetahuan Alam Universitas Gadjah Mada \\ *Corresponding Author E-mail: nurulindarti@ugm.ac.id
}

\begin{abstract}
This study focuses on the effect of five supply chain practices: supplier integration, internal integration, customer integration, information sharing, and postponement on supply chain performance. We conducted a survey by distributing questionnaires to 102 companies in the sector of batik in Surakarta, using purposive sampling. The findings show that in general, supply chain practices have impact on supply chain performance. More specifically, the internal integration and information sharing have significant positive effects on supply chain performance. Meanwhile, the study also finds that the supplier integration and customer integration do not significantly influence supply chain performance. Interestingly, the current study finds that postponement has a negative effect on supply chain performance.
\end{abstract}

Keywords: supply chain practices, chain performance, small medium eterprise, batik industry

\begin{abstract}
Abstrak
Penelitian ini bertujuan menguji pengaruh praktik-praktik rantai pasokan yang terdiri dari integrasi pemasok, integrasi internal, integrasi pelanggan, berbagi informasi, dan penundaan (postponement)) terhadap kinerja rantai pasokan. Survei menggunakan kuesioner dilakukan pada 102 UKM Batik, di Surakarta dengan teknik purposive. Hasil penelitian menunjukkan bahwa secara keseluruhan praktik-praktik rantai pasokan berpengaruh terhadap kinerja rantai pasokan. Integrasi internal dan berbagi informasi merupakan praktik-praktik yang berpengaruh positif pada kinerja rantai pasokan. Sementara itu, integrasi pemasok dan integrasi pelanggan tidak berpengaruh pada kinerja rantai pasokan. Menariknya, studi ini menemukan bahwa penundaan berpengaruh negatif terhadap kinerja rantai pasokan.
\end{abstract}

Kata kunci: praktik-praktik rantai pasokan, kinerja rantai pasokan, usaha kecil menengah, industri batik

JEL: D24, L26, L67, M16

DOI: 10.20885/jsb.vol21.iss1.art2

\section{Pendahuluan}

Dalam literatur manajemen rantai pasokan, peran dan kinerja manajemen rantai pasokan pada penciptaan keunggulan bersaing perusahaan tidak terbantahkan (seperti: Ellinger (2000), Sundram, Ibrahim, dan Govindaraju (2011)). Secara lebih spesifik, peran kinerja rantai pasokan antara lain adalah: 1) menghasilkan kinerja yang lebih baik daripada pesaing; 2) lebih responsif dalam memenuhi kebutuhan dan permintaan konsumen secara umum ataupun secara khusus; 3) dapat mencapai jumlah pengiriman tertentu pada tanggal tertentu barang tersebut dikirim; dan 4) dapat berkolaborasi dengan baik dengan para pemasoknya (lihat reviu dari Gimenez dan Ventura (2003)).

Studi tentang kinerja rantai pasokan dalam satu dekade terakhir ini mengalami perkembangan yang cukup pesat. Banyak penelitian yang telah dilakukan untuk mengidentifikasi faktor-faktor yang berpengaruh pada kinerja rantai pasokan (seperti Beamon, 1999; Gunasekaran, Patel, dan McGaughey, 2004; Sundram et al., 2011; Ibrahim dan Ogunyemi, 2012; Abdallah, Obeidat, dan Aqqad, 2014; Seo, Dinwoodie, dan Kwak, 2014). Berdasarkan literatur, studi kinerja rantai pasokan dapat diklasifikasikan menjadi dua kategori (seperti Sezen (2008)). Kategori pertama fokus pada pengukuran kinerja rantai pasokan, di antaranya dilakukan oleh Beamon (1999) dan 
Gunasekaran et al. (2004). Dalam kategori pertama, belum ada kesepakatan di antara para peneliti mengenai pengukuran kinerja rantai pasokan terbaik (Ibrahim dan Ogunyemi, 2012). Kategori kedua menitikberatkan pada faktor-faktor penentu kinerja rantai pasokan (seperti: Sundram et al., 2011). Kategori kedua berfokus pada faktor-faktor yang mampu menjelaskan mengapa kinerja suatu rantai pasokan lebih baik dibandingkan yang lain. Faktor-faktor yang digunakan merupakan aktivitas-aktivitas yang dilakukan untuk mendorong keefektifan rantai pasokan (Sundram et al., 2011). Aktivitas-aktivitas rantai pasokan ini sering disebut dengan praktik-praktik rantai pasokan.

Survei literatur tentang pengukuran kinerja rantai pasokan menunjukkan bahwa pengukuran kinerja rantai pasokan dibagi menjadi tiga dimensi (Beamon, 1999; Sezen, 2008): a) kinerja sumberdaya; b) kinerja output; dan c) kinerja fleksibilitas (Beamon (1999); Sezen (2008); Jeong dan Hong (2007); Vanichchinchai dan Igel (2009); Ibrahim dan Ogunyemi (2012)). Jeong dan Hong (2007) mengukur kinerja rantai pasokan dari aspek kehandalan pengiriman, responsivitas, fleksibilitas, biaya, dan efisiensi. Vanichchinchai dan Igel (2009) menggunakan variabel biaya, fleksibilitas, ketangkasan, dan responsivitas untuk mengukur kinerja rantai pasokan. Senada dengan hal tersebut, peneliti lain (Ibrahim dan Ogunyemi, 2012) juga menggunakan fleksibilitas dan efisiensi dalam pengukuran kinerja rantai pasokan. Ada pula Abdallah et al. (2014) yang menggunakan keefektifan dan efisiensi rantai pasokan sebagai dimensi dalam pengukuran rantai pasokan. Aspek efisiensi dan keefektifan telah banyak digunakan dalam literatur untuk mengukur kinerja rantai pasokan (seperti Li, Ragu-Nathan, Ragu-Nathan, dan Subba Rao, 2006; Lee, Kwon, dan Severance, 2007; Ibrahim dan Ogunyemi, 2012). Dalam mengukur keefektifan rantai pasokan, Gunasekaran et al. (2004) mengemukakan bahwa fleksibilitas merupakan variabel yang paling penting dan kritis. Berdasarkan uraian tersebut, dimensi yang paling dominan dan sering digunakan adalah dimensi kinerja fleksibilitas dan dimensi kinerja efisiensi. Kedua dimensi tersebut juga dianggap mewakili secara keseluruhan dimensi yang ada (Abdallah et al., 2014).

Literatur manajemen rantai pasokan juga menunjukkan bahwa beberapa peneliti (seperti Flynn, Huo, dan Zhao, 2010; Sundram et al., 2011; Ibrahim dan Ogunyemi, 2012; Abdallah et al., 2014; Seo et al., 2014) telah melakukan kajian tentang faktor-faktor yang mempengaruhi kinerja rantai pasokan yang sering disebut dengan praktik-praktik rantai pasokan. Peneliti-peneliti lain seperti Tan, Lyman, dan Wisner (2002); Zhou dan Benton (2007); Chow, Madu, Kuei, Lu, Lin, dan Tseng, (2008); Robb, Xie, dan Arthanari (2008); Jabbour, Filho, Viana, dan Jabbour (2011) melakukan pembuktian empiris mengenai konstruksi rerangka praktik-praktik manajemen rantai pasokan. Sebagai contoh, Tan et al. (2002) mengidentifikasi 24 praktik rantai pasokan dan menghasilkan enam konstruk praktik-praktik rantai pasokan yang sesuai untuk konteks perusahaan manufaktur di Amerika Serikat. Keenam konstruk tersebut yaitu: integrasi rantai pasokan, berbagi informasi, karakteristik rantai pasokan, manajemen layanan pelanggan, kedekatan geografis, dan kapasitas just in time (JIT). Dengan mengambil konteks perusahaan manufaktur elektronik di Amerika Utara, Zhou dan Benton (2007) juga menggunakan konstruk berbagi informasi, perencanaan rantai pasokan, produksi just in time (JIT), dan praktik pengiriman untuk menguji pengaruhnya pada kinerja pengiriman. Hasilnya praktik rantai pasokan yang efektif merupakan faktor penting dalam mencapai kinerja rantai pasokan yang baik. Di Cina dan Taiwan, penelitian yang dilakukan oleh Robb et al. (2008) dan Chow et al. (2008) menggunakan beberapa konstruk yang sama dan menambahkan konstruk yang berbeda. Chow et al. (2008) menggunakan konstruk manajemen pemasok dan pelanggan, fitur rantai pasokan, kecepatan dan komunikasi, dan berbagi informasi untuk mengkaji perbandingan kinerja organisasi antara perusahaan di Taiwan dan Amerika. Hasilnya praktik rantai pasokan tersebut berpengaruh secara langsung terhadap kinerja organisasi perusahaan di Taiwan dan tidak untuk konteks perusahaan di Amerika. Robb et al. (2008) menggunakan hubungan pelanggan, hubungan pemasok, e-commerce, dan perangkat lunak perusahaan untuk menguji pengaruh praktik rantai pasokan terhadap kinerja pasar pada perusahaan furnitur di Cina. Praktik-praktik rantai pasokan tersebut ditemukan tidak berpengaruh terhadap kinerja pasar pada perusahaan furnitur. Penelitian lain dengan mengambil konteks perusahaan elektronik di Brazil 
(Jabbour et al., 2011) menemukan empat praktik rantai pasokan yang berpengaruh pada kinerja perusahaan, yakni 1) integrasi rantai pasokan untuk mendukung perencanaan dan pengendalian produksi; 2) berbagi informasi tentang produk dan strategi penargetan; 3) hubungan strategis dengan pelanggan dan pemasok; dan 4) dukungan pesanan pelanggan.

Berdasarkan uraian di bagian sebelumnya, secara spesifik penelitian ini dilakukan dengan mendasarkan pada tiga masalah utama. Pertama, menurut literatur manajemen rantai pasokan, penelitian tentang praktik-praktik rantai pasokan masih menggunakan berbagai konstruk yang berbeda-beda dan memberikan temuan yang belum konklusif. Hal tersebut membuat para peneliti menjadi kebingungan (Abdallah et al., 2014). Setidaknya, terdapat lima konstruk atau dimensi praktik-praktik rantai pasokan yang sering digunakan dalam berbagai penelitian (e.g. Tan et al. (2002); Zhou dan Benton (2007); Chow et al. (2008); Robb et al. (2008); Flynn et al. (2010); Sundram et al. (2011); Jabbour et al. (2011); Ibrahim dan Ogunyemi (2012); Abdallah et al. (2014); Seo et al., (2014)). Praktik-praktik rantai pasokan tersebut adalah: 1) integrasi pemasok, 2) integrasi internal, 3) integrasi pelanggan, 4) tingkat dan kualitas berbagi informasi, dan 5) penundaan. Selain itu, kelima faktor tersebut dianggap mewakili seluruh faktor yang lain yang mana faktor tersebut menurut Gorane dan Kant (2015) merupakan faktor yang utama dalam praktik rantai pasokan yang menunjukkan adanya hubungan dalam rantai pasokan.

Kedua, mayoritas penelitian tentang praktik-praktik rantai pasokan dan pengaruhnya pada kinerja perusahaan lebih banyak dilakukan di negara-negara maju seperti Amerika Serikat (Li et al., 2006; Lee et al., 2007; Zelbst, Green, Sower, dan Reyes, 2009), Austria, Finlandia, Italia (Pamela dan Pietro, 2011), Jepang (Narasimhan dan Kim, 2002), Jerman (Pamela dan Pietro, 2011), Korea (Seo et al., 2014), Spanyol (Gimenez dan Ventura, 2003), Swedia (Pamela dan Pietro, 2011). Berdasarkan ulasan atas 23 artikel tentang praktik-praktik rantai pasokan, delapan penelitian dilakukan di negara berkembang, khususnya di Cina (Flynn et al., 2010; Huo, 2012) dan Turki (Sezen, 2008), dan 15 penelitian dilakukan di negara maju. Temuan ini serupa dengan hasil penelitian yang dilakukan oleh Gorane dan Kant (2015) yang menemukan bahwa dari 382 penelitian yang dirangkumnya, hanya $15 \%$ penelitian dilakukan di negara berkembang. Hal ini menjadi menarik untuk diteliti kembali khususnya dalam konteks negara berkembang seperti Indonesia. Apalagi adanya perbedaan hasil yang diperoleh dari penelitian-penelitian sebelumnya kebanyakan dijumpai pada penelitian dengan konteks negara berkembang (e.g. Sezen (2008); Flynn et al. (2010); Sundram et al. (2011); Abdallah et al., 2014). Lebih lanjut, Abdallah et al. (2014) mengatakan bahwa negara berkembang menghadapi tantangan nyata untuk meningkatkan kemampuan operasional, termasuk manajemen rantai pasokan, agar mampu bersaing dan bertahan dalam lingkungan yang kompetitif. Karenanya, penelitian tentang pengaruh praktik-praktik rantai pasokan terhadap kinerja rantai pasokan dalam konteks negara berkembang yaitu Indonesia menjadi relevan untuk dilakukan.

Ketiga, konteks atau obyek penelitian praktik-praktik rantai pasokan di penelitian sebelumnya banyak yang menyasar pada perusahaan manufaktur dengan skala besar (e.g. Zhao, Xie dan Zhang (2002); Li et al. (2006); Lee et al. (2007); Sezen (2008); Cook, Heiser, dan Sengupta (2011); Pamela dan Pietro (2011); Huo (2012); Abdallah et al. (2014)) dan masih relatif sedikit yang mengangkat konteks usaha kecil dan menengah. Penelitian ini mengambil konteks UKM sektor batik (selanjutnya disebut UKM batik) di Indonesia dengan beberapa pertimbangan. Industri batik di Indonesia yang dalam kategori industri kreatif saat ini tengah mengalami perkembangan yang signifikan. Setelah batik mendapat pengakuan dari UNESCO tujuh tahun silam, pemerintah melalui Kementrian Perindustrian telah mencatat setidaknya ada 47.775 unit usaha batik yang tersebar di seluruh Indonesia pada tahun 2015. Tumbuh suburnya Industri Kecil Menengah batik berbanding lurus dengan kenaikan nilai ekspornya. Berdasarkan data Kementrian Perindustrian dalam lima tahun sejak 2011 hingga 2015, industri ini tumbuh 14,7\% dari 41.623 unit menjadi 47.775 unit, dengan nilai pembelian bahan baku meningkat 12,8\% dari tahun 2011 senilai Rp4.137 triliun menjadi Rp4.746 triliun pada tahun 2015. Nilai tambah batik tumbuh 14,7\% dari tahun 2011 senilai 
Rp1,909 triliun menjadi Rp2,191 triliun. Disamping itu, peminat batik dari mancanegara yang meningkat pun tecermin dari nilai ekspor batik yang naik 14,7\% dari tahun 2011 senilai Rp43,96 triliun menjadi Rp50,44 triliun pada 2015. Tenaga kerja pada industri batik juga mengalami peningkatan, selama 2011-2015 tumbuh 14,7\% dari 173.829 orang menjadi 199.444 orang.

Penelitian ini mengambil Kota Surakarta, Solo sebagai fokus tempat penelitian karena Kota Surakarta dinobatkan menjadi Kota Ekonomi Kreatif oleh UNESCO di 2013 dikarenakan batiknya. Perkembangan batik di Surakarta sendiri juga mengalami peningkatan. Menurut data BPS Kota Surakarta tahun 2015 ada 170 usaha batik, baik produsen atau retailer atau keduanya yang berada di Surakarta. Pada tahun 2015, batik menjadi satu dari dua komoditi Kota Solo yang tetap meningkat ekspornya baik dari sisi nilai maupun volumenya. Dinas Perindustrian dan Perdagangan Kota Surakarta mencatat nilai ekspor batik meningkat dari Rp125,5 miliar menjadi Rp144,55 miliar pada tahun 2015. Selain itu, Surakarta juga merupakan produsen batik terbanyak di JawaTengah (Sarwoto, 2015).

Pendek kata, berdasarkan pemaparan di atas, penelitian ini ditujukan untuk mencari jawaban atas pertanyaan utama apakah praktik-praktik rantai pasokan berpengaruh pada kinerja rantai pasokan. Tulisan dibagi menjadi lima bagian. Bagian pertama, pendahuluan yang menguraikan latar belakang dan rumusan masalah. Dilanjutkan bagian kedua, Kajian Pustaka yang berisi uraian praktik-praktik rantai pasokan dan kinerja rantai pasokan serta hubungan keduanya yang dirangkum dalam model penelitian. Bagian Ketiga, memaparkan tentang metodologi penelitian mencakup desain penelitian, instrumen penelitian dan hasil pengujian instrumen. Bagian Keempat adalah Hasil dan Pembahasan. Bagian terakhir yaitu penutup yang berisi simpulan, saran penelitian selanjutnya dan implikasi manajerial.

\section{Kajian Pustaka}

\section{Praktik-Praktik Rantai Pasokan}

Praktik-praktik rantai pasokan merupakan seperangkat aktivitas yang digunakan untuk mendorong keefektifan rantai pasokan ( $\mathrm{Li}$ et al., 2006). Terdapat tujuan ganda dari manajemen rantai pasokan yang dapat dijelaskan melalui praktik-praktik rantai pasokan (Gorane dan Kant, 2015). Tujuan tersebut adalah untuk meningkatkan kinerja suatu organisasi dan untuk meningkatkan kinerja rantai pasokan secara keseluruhan. Hal senada juga diungkapkan Li et al. (2006) bahwa untuk tetap kompetitif, organisasi atau perusahaan harus menyadari pentingnya praktik-praktik rantai pasokan tidak hanya untuk meningkatkan kinerja perusahaan sendiri akan tetapi juga berkoordinasi dengan mitra rantai pasokan untuk meningkatkan kinerja bersama. Implementasi yang sukses dari suatu praktik rantai pasokan akan mengakibatkan kepuasan pelanggan yang lebih baik dan kepuasan pelanggan akan membawa kepada kinerja keuangan yang lebih baik (Ou, Liu, Hung, dan Yen, 2010).

Berdasarkan ulasan di awal, terdapat lima praktik-praktik rantai pasokan yang digunakan dalam penelitian ini yakni, integrasi pemasok, integrasi internal, integrasi pelanggan, berbagi informasi, dan penundaan. Praktik-praktik tersebut dijelaskan pada bagian berikut.

\section{Integrasi pemasok}

Gimenez dan Ventura (2003) mendefinisikan integrasi pemasok sebagai kesatuan dan kepaduan kegiatan logistik melintasi batas-batas perusahaan atau organisasi yang mencakup antara pemasok dengan produsen. Flynn et al. (2010) menyebutkan bahwa integrasi pemasok merupakan salah satu faktor penting yang memungkinkan anggota rantai pasokan bertindak secara terpadu. Hal ini dilakukan untuk memaksimalkan nilai rantai pasokan tersebut. Menurut Li et al. (2006), integrasi pemasok merupakan hubungan jangka panjang antara organisasi dan pemasok. Hubungan tersebut mempunyai dua tujuan yaitu: a) meningkatkan kemampuan operasional dan strategik perusahaan, dan b) membantu perusahaan mencapai manfaat yang berkelanjutan (Li et al., 2006). Beberapa 
manfaat yang didapat dari penerapan integrasi pemasok antara lain: a) berkurangnya biaya, b) berkurangnya persediaan, c) minimnya waktu tunggu, dan d) meningkatnya keunggulan kompetitif (Gimenez dan Ventura, 2003).

\section{Integrasi internal}

Integrasi internal merupakan sebuah praktik rantai pasokan yang mengacu pada sejauh mana perusahaan mengatur kembali strategi dan proses dalam organisasi untuk memuaskan permintaan pelanggan (Kahn dan Mentzer, 1996). Integrasi internal sendiri menurut Gimenez dan Ventura (2003) merupakan kesatuan dan kepaduan antar batas-batas fungsional dalam suatu perusahaan. Senada diungkapkan oleh Wong, Boon-itt, dan Wong (2011) yang menyatakan bahwa integrasi internal merupakan suatu sistem stratejik lintas fungsi dan tanggung jawab bersama seluruh fungsi.

Dalam integrasi internal, terjadi kolaborasi di seluruh fungsi yakni: desain produk, pengadaan, produksi, penjualan, dan distribusi yang bertujuan untuk memenuhi kebutuhan pelanggan (Wong et al., 2011). Ketiadaan integrasi internal dalam perusahaan akan menyebabkan pekerjaan yang berlebihan dan sumberdaya yang terbuang, serta mengurangi kualitas dan kinerja perusahaan (Pagell, 2004). Dalam penelitian kinerja rantai pasokan yang dilakukan di Spanyol, Gimenez dan Ventura (2003) menemukan bahwa perusahaan yang menerapkan integrasi internal dengan baik dalam rantai pasokannya akan memiliki kinerja yang lebih baik dibandingkan pesaingnya. Kinerja tersebut antara lain merespon kebutuhan dan keinginan pelanggan, merespon kebutuhan yang spesial, pemenuhan jumlah dan tanggal pengiriman, dan kolaborasi dalam meluncurkan produk baru (Gimenez dan Ventura, 2003).

\section{Integrasi pelanggan}

Integrasi pelanggan merupakan bagian yang tak terpisahkan dan komponen penting dalam rantai pasokan (e.g. Tan, Kannan, dan Handheld (1998)). Menurut Wong et al. (2011), integrasi pelanggan adalah kesatuan dan kepaduan yang melibatkan kolaborasi dan berbagi informasi antara perusahaan dan pelanggannya untuk meningkatkan kepuasan pelanggan. Selain berkolaborasi dan berbagi informasi, menurut Flynn et al. (2010) kesatuan dan kepaduan yang dilakukan antara manufaktur dan pelanggan meliputi koordinasi mengenai bangunan strategi, praktik-praktik, dan proses interorganisasi.

Perusahaan yang menerapkan integrasi pelanggan dengan baik akan mampu memahami ekspektasi dan peluang pasar (Wong et al., 2011). Hal tersebut berkontribusi pada kinerja perusahaan untuk merespon lebih cepat dan lebih akurat apa yang menjadi kebutuhan dan keinginan pelanggan. Selain itu, integrasi pelanggan juga mampu meningkatkan kinerja rantai pasokan melalui hubungan jangka panjang dengan pelanggan untuk memenuhi kepuasan pelanggan (Li et al., 2006).

\section{Berbagi informasi}

Berbagi informasi dalam rantai pasokan pada penelitian ini terbagi menjadi dua yakni tingkat berbagi informasi dan kualitas berbagi informasi. Menurut Li et al. (2006) tingkat berbagi informasi mencerminkan sejauh mana informasi yang penting dan eksklusif dikomunikasikan dari satu pihak ke pihak yang lain seperti dari pemasok ke produsen, dan dari ritel ke pelanggan. Informasi yang dikomunikasikan berkaitan dengan informasi pasar, produk, dan pelanggan (Mentzer, Keebler, Dewitt, Min, Nix, Smith, dan Zacharia, 2001).

Tingkat berbagi informasi dengan mitra merupakan elemen penting dari rantai pasokan yang mencerminkan kuantitas dari informasi yang dibagikan (Sundram et al., 2011). Semakin banyak informasi yang diberikan maka semakin efisien dan efektif pula komunikasi yang dibangun dalam rantai pasokan (Li dan Lin, 2006). Upaya berbagi informasi dan membuat informasi dapat diakses berbagai pihak dalam rantai pasokan, memungkinkan keputusan yang dibuat menjadi lebih cepat dan akurat. Hal ini pada akhirnya akan memberikan sumber keunggulan kompetitif bagi perusahaan (Moberg, Cutler, Gross, dan Speh, 2002). 
Kualitas berbagi informasi merupakan mutu yang didapatkan dalam pertukaran informasi. Faktor ini meliputi tingkat akurasi, ketepatan waktu, kredibilitas dan kecukupan informasi yang dipertukarkan (Li et al., 2006). Tingkat berbagi informasi dalam rantai pasokan merupakan hal yang penting. Akan tetapi dampaknya pada rantai pasokan bergantung pada informasi apa yang dibagikan, kapan dan dimana informasi dibagikan, serta dengan siapa informasi tersebut dibagikan (Sundram et al., 2011). Mitra rantai pasokan yang bertukar informasi secara teratur dapat bekerja sebagai satu kesatuan sehingga mampu merespon dengan cepat perubahan pasar. Selain itu, kualitas berbagi informasi yang dikelola dengan baik di internal dan antarperusahaan akan berpengaruh langsung pada peningkatan kinerja rantai pasokan (Moberg et al., 2002). Hal ini dikarenakan kualitas informasi yang dibagikan dapat mempengaruhi keputusan manajerial. Semakin berkualitas informasi yang dibagikan, semakin tepat keputusan yang diambil oleh manajer, dan semakin efektif pula manajemen rantai pasokannya (Raisinghani dan Meade, 2005).

\section{Penundaan}

Dalam artikelnya, Van Hoek, Vos, dan Commandeur (1999) mendefinisikan penundaan sebagai praktik bergerak maju sejauh mungkin satu atau lebih kegiatan/aktivitas ke suatu titik selanjutnya dalam rantai pasokan. Kemudian Van Hoek (2001) menyederhanakan pengertian penundaan menjadi penundaan aktivitas rantai pasokan sampai permintaan pelanggan diterima. Hal serupa juga diungkapkan oleh Heizer dan Render (2014) yang menjelaskan bahwa penundaan merupakan suatu aktivitas menunda modifikasi atau kustomisasi produk selama mungkin dalam proses produksi.

Terdapat beberapa manfaat yang diperoleh perusahaan apabila mengaplikasikan penundaan dalam rantai pasokannya. Perusahaan mampu mengendalikan risiko yang terkait dengan keberagaman produk dan permintaan yang tidak pasti. Selain itu, perusahaan juga dapat meningkatkan fleksibilitas, dan menjaga pilihan perusahaan terbuka sebelum tersedianya informasi yang cukup (Yang, Burns, dan Backhouse, 2005). Perusahaan juga mampu mengurangi biaya rantai pasokan dengan menjaga persediaan produk yang memiliki daya beda, mengurangi tingkat persediaan, meningkatkan keefektifan peramalan, memfasilitasi kustomisasi massal, dan mengurangi waktu siklus produksi (Li et al., 2006).

\section{Kinerja Rantai Pasokan}

Untuk menang dalam lingkungan yang baru, rantai pasokan perlu dikembangkan secara berkelanjutan yang membutuhkan pengukuran kinerja untuk mencapainya (Hausman, 2002). Kinerja rantai pasokan harus diukur untuk mengkaji seberapa efisien rantai pasokan (Sillanpää, 2015). Neely, Richards, Mills, Platts, dan Bourne (1997) mendefinisikan pengukuran kinerja sebagai proses sistematis secara efisien dan efektif mengukur suatu konsep atau tindakan. Hal serupa diungkapkan oleh Lai, Ngai, dan Cheng (2002) yang menyatakan bahwa pengukuran kinerja merupakan keefektifan dan efisiensi dalam menyelesaikan tugas yang diberikan dalam kaitannya dengan seberapa baik tujuan terpenuhi.

Menurut Hausman (2002) kinerja rantai pasokan adalah kegiatan-kegiatan rantai pasokan untuk memenuhi kebutuhan pelanggan akhir, meliputi ketersediaan barang, pengiriman tepat waktu, dan persediaan kapasitas rantai pasokan, yang dilakukan seresponsif mungkin. Kinerja rantai pasokan mengacu pada perluasan kegiatan rantai pasokan dalam memenuhi kebutuhan pelanggan akhir, termasuk ketersediaan produk, pengiriman tepat waktu, dan semua persediaan dan kapasitas yang diperlukan dalam rantai pasokan untuk memberikan kinerja yang responsif (Hausman, 2002). Dari penjelasan tersebut, dapat disimpulkan bahwa pengukuran kinerja rantai pasokan adalah suatu proses/cara yang sistematis untuk menghitung kemampuan dari rantai pasokan.

Pengukuran kinerja rantai pasokan merupakan salah satu cara yang penting dilakukan untuk memberikan pemahaman lebih mendalam mengenai rantai pasokan dan meningkatkan kinerja keseluruhan (Chen dan Paulraj, 2004). Oleh karena itu, penting bagi perusahaan untuk melakukan pengukuran kinerja rantai pasokannya untuk melihat seberapa efisien dan efektif rantai pasokan 
dalam perusahaan mereka. Pengukuran kinerja rantai pasokan telah banyak dilakukan oleh para peneliti (seperti Baemon, 1999; Gunasekaran et al., 2004; Li et al.,2006; Sezen, 2008; Ibrahim dan Ogunyemi, 2012; Abdallah et al. 2014). Akan tetapi, belum kesepakatan mana yang merupakan pengukuran terbaik terhadap kinerja rantai pasokan (Abdallah et al. 2014).

Kinerja output/biaya dan kinerja fleksibilitas merupakan dua dimensi kinerja yang paling banyak digunakan oleh para peneliti (seperti Beamon, 1999; Sezen, 2008; Jeong dan Hong, 2007; Vanichchinchai dan Igel, 2009). Kedua kinerja tersebut digunakan dalam membangun konstruk kinerja rantai pasokan. Menurut Ibrahim dan Ogunyemi (2012) kinerja output/biaya dan kineja sumberdaya merupakan bagian dari kinerja efisiensi sedangkan kinerja responsivitas merupakan bagian dari kinerja fleksibilitas. Dengan demikian, pada penelitian ini dimensi fleksibilitas dan efisiensi digunakan untuk mengukur kinerja rantai pasokan. Kedua dimensi tersebut dijadikan satu kesatuan menjadi dimensi kinerja rantai pasokan.

\section{Pengembangan Hipotesis}

Penelitian ini mengembangkan 5 (lima) hipotesis yang menguji pengaruh variabel independen terhadap variabel dependen. Kelima variabel independen yaitu praktik-praktik rantai pasokan (integrasi pemasok, integrasi internal, integrasi pelanggan, berbagi informasi, dan penundaan) dianggap mewakili praktik-praktik rantai pasokan yang ada. Selain itu, kelima variabel tersebut merupakan praktik dasar yang digunakan dalam rantai pasokan.

Integrasi pemasok merupakan kesatuan dan kepaduan kegiatan logistik melintasi batasbatas perusahaan atau organisasi yang mencakup antara pemasok dengan produsen (Gimenez dan Ventura, 2003). Pada penelitiannya di Spanyol, Gimenez dan Ventura (2003) menemukan bahwa integrasi pemasok memberikan pengaruh positif terhadap kinerja perusahaan. Pengaruh ini juga berimbas pada berkurangnya biaya, kehabisan persediaan, dan waktu tunggu serta meningkatnya keuggulan kompetitif yang diperoleh perusahaan. Lee et al. (2007) meneliti menemukan bahwa integrasi pemasok memberikan pengaruh positif terhadap kinerja perusahaan. Ibrahim dan Ogunyemi (2012) dalam penelitiannya yang dilakukan pada industri tekstil dan pakaian juga menemukan bahwa integrasi pemasok berpengaruh positif terhadap kinerja rantai pasokan. Seo et al. (2014) dalam penelitiannya yang dilakukan di Korea juga menemukan bahwa integrasi pemasok berpengaruh positif terhadap kinerja rantai pasokan. Dengan demikian, dari uraian tersebut peneliti mengusulkan sebuah hipotesis sebagai berikut,

H1: Integrasi pemasok berpengaruh positif terhadap kinerja rantai pasokan.

Pada penelitian sebelumnya (seperti Narasimhan dan Kim, 2002; Gimenez dan Ventura, 2003; Droge, Jayaram, dan Vickery, 2004; dan Abdallah et al., 2014), integrasi internal diyakini sebagai salah satu praktik rantai pasokan yang paling konsisten dalam mengukur kinerja rantai pasokan. Hal ini karena pengaruh integrasi internal selalu ditemukan positif terhadap kinerja rantai pasokan. Pagell (2004) menyatakan bahwa integrasi internal merupakan faktor terpenting dalam praktik rantai pasokan perusahaan. Kualitas dan kinerja perusahaan bisa berkurang apabila tidak terdapat integrasi internal dalam perusahaan. Menurut Huo (2012) perusahaan akan kesulitan berkolaborasi dengan anggota rantai pasokan jika tidak ada kerjasama dan integrasi di berbagai fungsi internal perusahaan. Narasimhan dan Kim (2002), Gimenez dan Ventura (2003), Droge et al. (2004) dan Abdallah et al. (2014) menemukan bahwa integrasi internal berpengaruh positif terhadap kinerja rantai pasokan. Secara lebih spesifik, Stank, Daugherty, dan Ellinger (1999) membuktikan bahwa integrasi antardepartemen di perusahaan manufaktur Amerika. Dari pemaparan tersebut, dapat diambil sebuah hipotesis sebagai berikut, H2: Integrasi internal berpengaruh positif terhadap kinerja rantai pasokan.

Praktik rantai pasokan ketiga yang digunakan pada penelitian ini adalah integrasi pelanggan. Integrasi yang baik dengan anggota rantai pasokan, termasuk pelanggan, sangat dibutuhkan 
untuk keberhasilan penerapan program manajemen rantai pasokan (Moberg et al., 2002). Menurut Wong et al. (2011) perusahaan yang menerapkan integrasi pelanggan dengan baik akan mampu memahami ekspektasi dan peluang pasar. Hal tersebut berkontribusi pada kinerja perusahaan dalam memberikan respon yang lebih cepat dan lebih akurat atas kebutuhan dan keinginan pelanggan. Narasimhan dan Kim (2002) menemukan bahwa integrasi pelanggan mampu meningkatkan kinerja perusahaan. Selain mampu meningkatkan kinerja perusahaan, integrasi pelanggan juga mampu meningkatkan kinerja rantai pasokan (Gimenez dan Ventura, 2003; Droge et al., 2004). Selain ketiga penelitian tersebut, penelitian lain (seperti Li et al., 2006; Lee et al., 2007; Pamela dan Pietro, 2011) juga menemukan bahwasanya integrasi pelanggan berpengaruh positif terhadap kinerja rantai pasokan. Dari uraian tersebut, dapat diusulkan sebuah hipotesis sebagai berikut,

H3: Integrasi pelanggan berpengaruh positif terhadap kinerja rantai pasokan.

Berbagi informasi merupakan merupakan jumlah dan mutu informasi yang dibagikan dalam rantai pasokan. Perusahaan yang menerapkan berbagi informasi dengan baik mampu meningkatkan kinerja. Peningkatan kinerja dapat berupa: a) peningkatan respon pelanggan, b) penurunan biaya, c) peningkatan kualitas layanan pada pelanggan, dan d) penurunan tingkat kompleksitas (Zhao et al., 2002). Abdallah et al. (2014) menemukan bahwa berbagi informasi berpengaruh positif dan signifikan terhadap kinerja rantai pasokan. Peneliti lain (seperti Moberg et al., 2002; Zhao et al., 2002; Cook et al., 2011; Jabbour et al., 2011) juga menemukan bahwa berbagi informasi dalam rantai pasokan memberikan pengaruh yang positif bagi kinerja rantai pasokan. Berdasarkan argumentasi tersebut, hipotesis yang akan dibuktikan adalah sebagai berikut,

H4: Berbagi informasi berpengaruh positif terhadap kinerja rantai pasokan.

Penundaan merupakan salah satu strategi dalam rantai pasokan yang digunakan untuk mengurangi ketidakpastian dan biaya yang ditanggung sementara di lain pihak juga untuk memuaskan kebutuhan pelanggan (Boone, Craighead, dan Hanna, 2007). Penundaan memungkinkan sebuah organisasi menjadi fleksibel dalam mengembangkan produk dengan versi yang berbeda untuk memenuhi kebutuhan pelanggan yang berubah, dan untuk membedakan produk atau memodifikasi fungsi permintaan (Waller, Dabholkar, dan Gentry, 2000). Pada penelitian sebelumnya, Yang, Yang, dan Williams (2010) menemukan bahwa penundaan memberikan manfaat di seluruh rantai pasokan. Hal ini terjadi karena penundaan mampu mengurangi biaya persediaan pada semua rantai pasokan. Selain itu, Yang, Yang, dan Wijngaard (2007) menemukan bahwa penundaan mampu meningkatkan kinerja rantai pasokan. Oleh sebab itu, sesuai pernyataan tersebut peneliti merumuskan hipotesis yakni:

H5: Penundaan berpengaruh positif terhadap kinerja rantai pasokan.

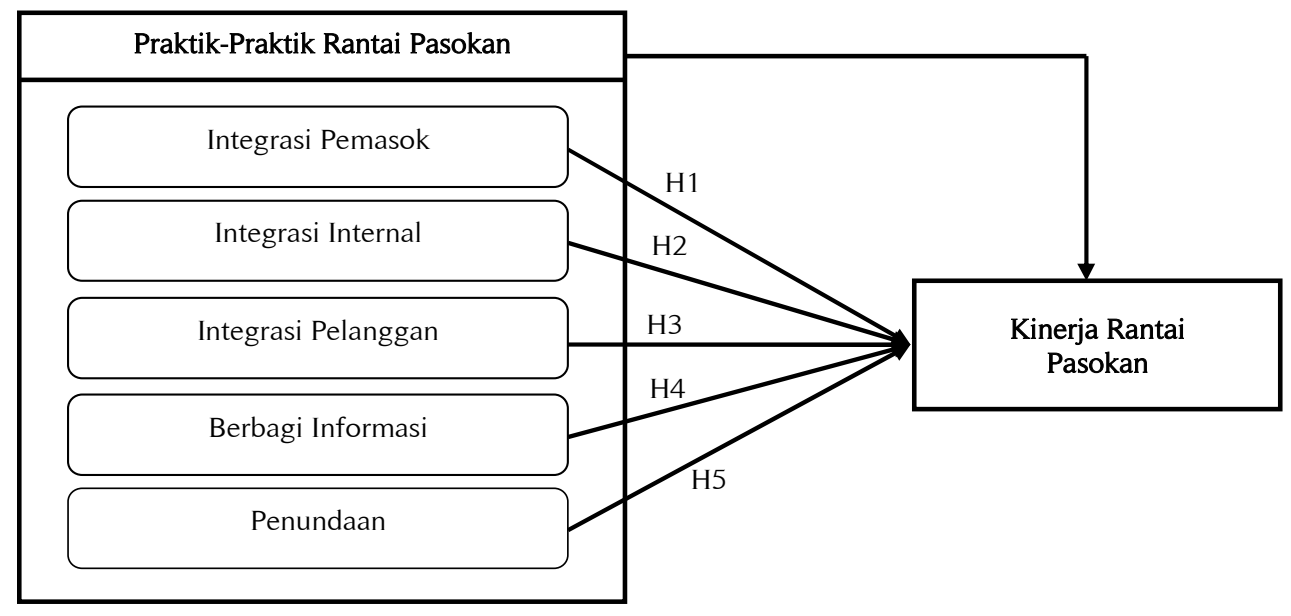

Gambar 1. Model Penelitian 


\section{Metodologi Penelitian}

\section{Desain Penelitian}

Penelitian ini menggunakan pendekatan kuantitatif dengan rerangka deduktif yang ditujukan untuk menguji hipotesis penelitian (Sekaran dan Bougie, 2013). Penelitian ini menguji pengaruh variabel independen yakni: integrasi pemasok, integrasi internal, integrasi pelanggan, berbagi informasi dalam rantai pasokan, dan penundaan pada variabel dependen yaitu kinerja rantai pasokan.

\section{Instrumen Penelitian}

Kuesioner adalah instrumen utama dalam penelitian ini. Kuesioner terdiri dari pertanyaan tentang demografi pemilik perusahaan dan perusahaan serta pernyataan-pernyataan mengenai praktikpraktik rantai pasokan dan kinerja perusahaan (lihat Tabel 1). Seluruh item dalam variabel independen diukur dengan menggunakan 5 -poin skala Likert $[1=$ sangat tidak setuju; $5=$ sangat setuju]. Item-item dalam variabel dependen diukur dengan menggunakan 5-poin skala Likert [1= sangat tidak baik; $5=$ sangat baik].

Tabel 1. Variabel dan Definisi Operasional

\begin{tabular}{|c|c|c|c|c|}
\hline No. & Variabel & Definisi Operasional & Item & Sumber \\
\hline & \multicolumn{4}{|c|}{ Variabel Independen } \\
\hline 1. & $\begin{array}{l}\text { Integrasi } \\
\text { Pemasok }\end{array}$ & $\begin{array}{l}\text { Kesatuan dan kepaduan melintasi } \\
\text { batas-batas perusahaan yang } \\
\text { mencakup antara pemasok dan } \\
\text { produsen }\end{array}$ & 5 & $\begin{array}{l}\text { Li et al., (2006), Bratic (2011), } \\
\text { Sundram et al., (2011) dan } \\
\text { Ibrahim dan Ogunyemi (2012). }\end{array}$ \\
\hline 2. & Integrasi Internal & $\begin{array}{l}\text { Kesatuan dan kepaduan antar batas- } \\
\text { batas fungsional dalam suatu } \\
\text { perusahaan. }\end{array}$ & 5 & $\begin{array}{l}\text { Lee et al., (2007), Sezen (2008), } \\
\text { dan Flynn et al., (2010) }\end{array}$ \\
\hline 3. & $\begin{array}{l}\text { Integrasi } \\
\text { Pelanggan }\end{array}$ & $\begin{array}{l}\text { Kesatuan dan kepaduan yang } \\
\text { melibatkan kolaborasi dan berbagi } \\
\text { informasi antara perusahaan dengan } \\
\text { pelanggan untuk meningkatkan } \\
\text { kepuasan pelanggan. }\end{array}$ & 5 & $\begin{array}{l}\text { Li et al., 2006; Sezen, 2008; Flynn } \\
\text { et al., 2011; Bratic, } \\
\text { 2011;Sundram et al., 2011; dan } \\
\text { Ibrahim dan Ogunyemi, 2012). }\end{array}$ \\
\hline 4. & $\begin{array}{l}\text { Berbagi } \\
\text { Informasi }\end{array}$ & $\begin{array}{l}\text { Kuantitas dan kualitas informasi } \\
\text { yang dibagikan atau dipertukarkan } \\
\text { yang meliputi tingkat akurasi, } \\
\text { ketepatan waktu, kredibilitas, dan } \\
\text { kecukupan informasi }\end{array}$ & 5 & $\begin{array}{l}\text { Li et al., (2006), Bratic (2011), } \\
\text { Sundram et al., (2011); Ibrahim } \\
\text { dan Ogunyemi (2012) }\end{array}$ \\
\hline \multirow[t]{2}{*}{5.} & Penundaan & $\begin{array}{l}\text { Aktivitas menunda modifikasi atau } \\
\text { kustomisasi produk selama mungkin } \\
\text { dalam proses produksi. }\end{array}$ & 3 & $\begin{array}{l}\text { Li et al., (2006), Bratic (2011), } \\
\text { Sundram et al., (2011); Ibrahim } \\
\text { dan Ogunyemi (2012) }\end{array}$ \\
\hline & \multicolumn{4}{|c|}{ Variabel Dependen } \\
\hline 6. & $\begin{array}{l}\text { Kinerja Rantai } \\
\text { Pasokan }\end{array}$ & $\begin{array}{l}\text { Menggunakan dua dimensi: } \\
\text { fleksibilitas dan efisiensi. } \\
\text { a) Efisiensi berarti penggunaan } \\
\text { input minimum pada rantai } \\
\text { pasokan; } \\
\text { b) Fleksibilitas terkait bagaimana } \\
\text { rantai pasokan memenuhi } \\
\text { kebutuhan unik dan variabilitas } \\
\text { permintaan pelanggan mencakup } \\
\text { kinerja pengiriman, respon } \\
\text { pelanggan, dan waktu ke pasar. }\end{array}$ & 10 & $\begin{array}{l}\text { Li et al., (2006), Sezen (2008), } \\
\text { dan Ibrahin dan Ogunyemi } \\
(2012) .\end{array}$ \\
\hline
\end{tabular}


Untuk menjamin kualitas data yang didapat, uji validitas ini dilakukan dengan menggunakan metode analisis faktor konfirmatori (dengan nilai factor loading $\geq 0,4$ ). Uji reliabilitas dilakukan dengan mendasarkan pada nilai Alfa Cronbach $\geq 0,6$. Berdasarkan hasil pengujian instrumen yang ditunjukkan pada Tabel 2, 32 item pernyataan terbukti valid (nilai factor loading=0,607-0,923) dan reliabel (nilai Alfa Cronbach=0,810-0,940). Hal ini berarti bahwa instrumen yang digunakan dalam penelitian ini memiliki kualitas yang valid dan handal.

Tabel 2. Hasil Uji Validitas dan Uji Reliabilitas

\begin{tabular}{|c|c|c|}
\hline Item & Factor Loading & Alfa Cronbach \\
\hline Integrasi Pemasok 2 & 0,630 & \multirow{4}{*}{0,810} \\
\hline Integrasi Pemasok 3 & 0,784 & \\
\hline Integrasi Pemasok 4 & 0,807 & \\
\hline Integrasi Pemasok 5 & 0,772 & \\
\hline Integrasi Internal 1 & 0,882 & \multirow{5}{*}{0,940} \\
\hline Integrasi Internal 2 & 0,851 & \\
\hline Integrasi Internal 3 & 0,733 & \\
\hline Integrasi Internal 4 & 0,891 & \\
\hline Integrasi Internal 5 & 0,874 & \\
\hline Integrasi Pelanggan 1 & 0,818 & \multirow{4}{*}{0,871} \\
\hline Integrasi Pelanggan 2 & 0,675 & \\
\hline Integrasi Pelanggan 4 & 0,849 & \\
\hline Integrasi Pelanggan 5 & 0,831 & \\
\hline Berbagi Informasi 1 & 0,898 & \multirow{10}{*}{0,940} \\
\hline Berbagi Informasi 2 & 0,879 & \\
\hline Berbagi Informasi 3 & 0,607 & \\
\hline Berbagi Informasi 4 & 0,758 & \\
\hline Berbagi Informasi 5 & 0,622 & \\
\hline Berbagi Informasi 6 & 0,730 & \\
\hline Berbagi Informasi 7 & 0,821 & \\
\hline Berbagi Informasi 8 & 0,675 & \\
\hline Berbagi Informasi 9 & 0,808 & \\
\hline Berbagi Informasi 10 & 0,801 & \\
\hline Posponement 1 & 0,781 & \multirow{3}{*}{0,874} \\
\hline Posponement 2 & 0,877 & \\
\hline Posponement 3 & 0,922 & \\
\hline Kinerja Rantai Pasokan 1 & 0,626 & \multirow{6}{*}{0,906} \\
\hline Kinerja Rantai Pasokan 2 & 0,707 & \\
\hline Kinerja Rantai Pasokan 3 & 0,923 & \\
\hline Kinerja Rantai Pasokan 4 & 0,905 & \\
\hline Kinerja Rantai Pasokan 5 & 0,802 & \\
\hline Kinerja Rantai Pasokan 6 & 0,628 & \\
\hline
\end{tabular}

\section{Tempat Penelitian, Responden dan Teknik Pengambilan Sampel}

Penelitian ini mengambil konteks UKM sektor batik di Kota Surakarta, Solo dengan pertimbangan menjadi adalah pusat industri batik di Indonesia dan faktor aksesibilitas peneliti dalam pengumpulan data. Pengambilan responden dilakukan dengan teknik purposive sampling (Sekaran dan Bougie, 2013). Responden penelitian ini adalah perusahaan batik berskala kecil dan menengah yang melakukan aktivitas produksi dan ritel. Karena melibatkan produsen dan peritel yang masuk dalam rantai pasokan, pembuatan pertanyaan dalam kuesioner menjadi tantangan sendiri. Kuesioner dibuat dalam perspektif relatif ketika berhubungan dengan aktor di rantai pasokan sebelumnya dan sesudahnya. Sebagai contoh, untuk mengukur integrasi pemasok, salah satu pertanyaannya adalah "Kualitas merupakan kriteria utama bagi perusahaan kami dalam memilih pemasok." Pemasok dari perspektif produsen dapat berupa pemasok bahan baku kain atau pewarna batik, sedangkan dari 
perspektif peritel adalah pemasok kain batik dan material produksi pakaian jadi lain. Contoh lain, ketika mengukur integrasi pelanggan, salah satu pertanyaan yang diajukan adalah "Perusahaan kami secara teratur mengantisipasi kebutuhan pelanggan." Pelanggan dari sisi produsen dapat diterjemahkan menjadi pedagang besar atau peritel, sedangkan dari sisi peritel diartikan dengan konsumen individual.

Selain itu, perusahaan yang diteliti, adalah perusahaan yang telah beroperasi minimal satu tahun. Hal ini ditentukan dengan pertimbangan bahwa aktivitas rantai pasokan sudah dilakukan di perusahaan. Perusahaan diwakili oleh pemilik atau pihak manajemen yang memiliki pengetahuan tentang perusahaan khususnya terkait dengan praktik rantai pasokan di perusahaannya. Kuesioner disebar pada bulan Mei-Agustus 2016 sebanyak 120 responden. Sebanyak 80 kuesioner kembali dan layak diolah (tingkat pengembangan sebesar 66,67\%).

\section{Hasil dan Pembahasan}

\section{Karakteristik Responden dan Perusahaan Batik}

Sebagian besar responden penelitian ini adalah 44 orang (55\%) laki-laki, rerata berumu 40 tahun, dan memiliki pendidikan SMA (48 orang atau 60\%). Dari aspek perusahaan, di atas 50\% (44 orang) responden adalah pemilik perusahaan batik, sisanya (36 orang) sebagai pengelola atau pihak manajemen (Lihat Tabel 3). Hampir sebagian besar responden (95\%) memiliki jumlah karyawan 119 orang yang merupakan ciri khas UKM di Indonesia (Lihat Tabel 4).

Tabel 3. Profil Responden Penelitian

\begin{tabular}{|c|c|c|c|}
\hline Profil & Kategori & Jumlah (orang) & Presentase \\
\hline \multirow{2}{*}{ Jenis Kelamin } & Laki-Laki & 44 & $55 \%$ \\
\hline & Perempuan & 36 & $45 \%$ \\
\hline \multirow{3}{*}{ Usia } & $20-30$ & 17 & $21 \%$ \\
\hline & $31-41$ & 27 & $34 \%$ \\
\hline & Di atas 41 & 36 & $45 \%$ \\
\hline \multirow{6}{*}{ Pendidikan terakhir } & SD & 3 & $3,75 \%$ \\
\hline & SMP & 6 & $7,5 \%$ \\
\hline & SMA & 48 & $60 \%$ \\
\hline & Diploma & 5 & $6,25 \%$ \\
\hline & Sarjana & 16 & $20 \%$ \\
\hline & Magister & 2 & $2,5 \%$ \\
\hline \multirow{2}{*}{ Jabatan } & Pemilik & 44 & $55 \%$ \\
\hline & Pengelola & 36 & $45 \%$ \\
\hline
\end{tabular}

Sumber: Data Primer, 2016

Seperti yang dirangkum pada Tabel 4, dari 80 perusahaan, rata-rata telah beroperasi selama 23 tahun. Ditinjau dari aspek pemasok, semua perusahaan batik memiliki pemasok dari dalam negeri, mayoritas $(73,75 \%)$ memiliki kurang lebih lima pemasok, dan 58\% tidak memiliki pemasok tidak tetap. Selain itu, hanya 2,5\% perusahaan mengaku juga menggunakan pemasok dari luar negeri. Perusahaan batik memiliki pelanggan dari dalam negeri $(100 \%)$, dan hanya $4(5 \%)$ perusahaan mengakui juga mendapatkan pelanggan dari luar negeri.

\section{Hasil Pengujian Hipotesis}

Untuk membuktikan hipotesis-hipotesis yang diajukan, penelitian ini menggunakan regresi linear berganda berdasarkan nilai-nilai adjusted $\mathrm{R}^{2}$, uji $F$, dan uji $t$. Sebelum metode regresi diterapkan, untuk memastikan bahwa tidak terdapat hubungan antar variabel independen, maka dilakukan 
pengujian multikolineritas, seperti yang dirangkum pada Tabel 5. Hasil pengujian korelasi menunjukkan bahwa tidak terdapat korelasi yang tinggi antar variabel-variabel independen dalam penelitian ini. Dengan demikian dapat disimpulkan bahwa pengujian hipotesis dengan regresi linier berganda dapat dilakukan.

Tabel 4. Profil Perusahaan

\begin{tabular}{|c|c|c|c|c|}
\hline \multicolumn{2}{|c|}{ Profil } & Kategori & $\begin{array}{c}\text { Jumlah } \\
\text { (Perusahaan) }\end{array}$ & Presentase \\
\hline \multirow{3}{*}{ Tahun Berdiri } & & 1950-1972 & 21 & $26,25 \%$ \\
\hline & & 1973-1995 & 15 & $18,75 \%$ \\
\hline & & 1996 ke atas & 44 & $55,00 \%$ \\
\hline \multirow{11}{*}{ Jumlah Pemasok } & \multirow{3}{*}{ Dalam Negeri } & $<5$ & 59 & $73,75 \%$ \\
\hline & & $5-10$ & 15 & $18,75 \%$ \\
\hline & & $>10$ & 6 & $7,50 \%$ \\
\hline & \multirow{2}{*}{ Luar Negeri } & Mempunyai & 2 & $2,5 \%$ \\
\hline & & Tidak mempunyai & 78 & $97,5 \%$ \\
\hline & & $<5$ & 62 & $77,5 \%$ \\
\hline & \multirow[t]{3}{*}{ Tetap } & $5-10$ & 14 & $17,5 \%$ \\
\hline & & $>10$ & 4 & $5,0 \%$ \\
\hline & & 0 & 58 & $72,50 \%$ \\
\hline & \multirow[t]{2}{*}{ Tidak Tetap } & $1-10$ & 19 & $23,75 \%$ \\
\hline & & $>10$ & 3 & $3,75 \%$ \\
\hline \multirow{11}{*}{ Jumlah Pelanggan } & \multirow{3}{*}{ Dalam Negeri } & $<10$ & 47 & $58,75 \%$ \\
\hline & & $10-50$ & 24 & $30,00 \%$ \\
\hline & & $>50$ & 9 & $11,25 \%$ \\
\hline & \multirow{2}{*}{ Luar Negeri } & Mempunyai & 4 & $5 \%$ \\
\hline & & Tidak mempunyai & 76 & $95 \%$ \\
\hline & \multirow{4}{*}{ Individu } & $<10$ & 49 & $61,25 \%$ \\
\hline & & $10-50$ & 23 & $28,75 \%$ \\
\hline & & $>50$ & 8 & $10,00 \%$ \\
\hline & & $<5$ & 65 & $81,25 \%$ \\
\hline & \multirow[t]{2}{*}{ Perusahaan } & $5-10$ & 12 & $15,00 \%$ \\
\hline & & $>10$ & 3 & $3,75 \%$ \\
\hline \multirow{6}{*}{ Jumlah Karyawan } & \multirow{3}{*}{ Tetap } & $1-4$ & 39 & $48,75 \%$ \\
\hline & & 5-19 & 37 & $46,25 \%$ \\
\hline & & $20-99$ & 4 & $5,00 \%$ \\
\hline & \multirow{3}{*}{ Tidak Tetap } & $<5$ & 73 & $91,25 \%$ \\
\hline & & $5-10$ & 4 & $5,00 \%$ \\
\hline & & $>10$ & 3 & $3,75 \%$ \\
\hline
\end{tabular}

Sumber: Data Primer, 2016

Tabel 5. Matriks korelasi antar variabel

\begin{tabular}{lrrrrrrr}
\hline & $\begin{array}{c}\text { Rata- } \\
\text { rata }\end{array}$ & $\begin{array}{c}\text { Simpangan } \\
\text { Baku }\end{array}$ & $\begin{array}{r}\text { Integrasi } \\
\text { Pemasok }\end{array}$ & $\begin{array}{c}\text { Integrasi } \\
\text { Internal }\end{array}$ & $\begin{array}{c}\text { Integrasi } \\
\text { Pelanggan }\end{array}$ & $\begin{array}{c}\text { Berbagi } \\
\text { Informasi }\end{array}$ & Penundaan \\
\hline Integrasi Pemasok & 4,04 & 0,39 & 1 & 0,19 & $0,45^{*}$ & $0,40^{*}$ & $-0,03$ \\
Integrasi Internal & 3,89 & 0,68 & & 1 & $0,33^{*}$ & $0,45^{*}$ & $-0,07$ \\
Integrasi Pelanggan & 4,11 & 0,41 & & & 1 & $0,39^{*}$ & $-0,10$ \\
Berbagi Informasi & 3,98 & 0,42 & & & & 1 & $-0,11$ \\
Penundaan & 2,44 & 0,80 & & & & & 1 \\
Kinerja Rantai & 4,12 & 0,38 & - & - & - & - & - \\
Pasokan & & & & & & & \\
\hline
\end{tabular}

Catatan: $\mathrm{N}=80 ; * p<0,01$ 
Tabel 6 menyajikan hasil pengujian hipotesis penelitian ini dengan menggunakan regresi linear berganda. Hasil nilai adjusted $\mathrm{R}^{2}=0,281(F=7,163 ; p<0,01)$ yang berarti bahwa model penelitian yang dibangun signifikan dengan kemampuan untuk menjelaskan pengaruh praktik-praktik rantai pasokan pada kinerja rantai pasokan sebesar $28,1 \%$. Secara lebih spesifik, uji $t$ terhadap variabel Integrasi Internal pada Kinerja Rantai Pasokan memberikan hasil $(\beta=0,249 ; p<0,05)$. Dengan demikian, Hipotesis 2 yang menyatakan bahwa integrasi internal berpengaruh positif terhadap kinerja rantai pasokan, terbukti. Hal serupa juga dilakukan untuk menjawab Hipotesis 4 yang berbunyi: berbagi informasi berpengaruh positif terhadap kinerja rantai pasokan. Hasil uji $t$ menunjukkan bahwa $(\beta=0,316 ; p<0,05)$ yang berarti bahwa Hipotesis 4 didukung oleh penelitian ini. Sementara itu, hasil pengujian $t$ pada Kinerja Rantai Pasokan untuk variabel Integrasi Pemasok $(\beta=-0,088 ; p>0,05)$, variabel Integrasi Pelanggan $(\beta=0,050 ; p>0,05)$ dan variabel Penundaan $(\beta=-$ $0,267 ; p<0,05)$. Berdasarkan hasil tersebut, dapat disimpulkan bahwa integrasi pemasok $(\mathrm{H} 1)$ dan integrasi pelanggan (H3) serta penundaan tidak berpengaruh positif terhadap kinerja rantai pasokan. Kedua hipotesis tersebut $(\mathrm{H} 1, \mathrm{H} 3$, dan $\mathrm{H} 5)$ tidak berhasil dibuktikan dalam penelitiannya. Tabel 6 merangkum hasil pengujian hipotesis dalam penelitian ini.

Tabel 5. Hasil Analisis Regresi Linear Berganda

\begin{tabular}{|c|c|c|c|}
\hline \multicolumn{4}{|c|}{ Variabel Dependen: Kinerja Rantai Pasokan (KRP) } \\
\hline Variabel Independen & Beta & $T$ & Sig. \\
\hline Konstanta & & 5,944 & 0,000 \\
\hline Integrasi Pemasok (IP) & $-0,088$ & $-0,804$ & 0,424 \\
\hline Integrasi Internal (II) & 0,249 & 2,311 & 0,024 \\
\hline Integrasi Pelanggan (IPEL) & 0,050 & 0,465 & 0,643 \\
\hline Berbagi Informasi (BI) & 0,316 & 2,735 & 0,008 \\
\hline Postponement(POS) & $-0,267$ & $-2,769$ & 0,007 \\
\hline \multicolumn{4}{|l|}{$\mathrm{R}=0,571 ; \mathrm{R}^{2}=0,326 ;$ Adjusted $\mathrm{R}^{2}=0,281$} \\
\hline Uji Simultan (F) I N = 80 & \multicolumn{3}{|c|}{$7,163(p<0,05)$} \\
\hline
\end{tabular}

Tabel 6. Ringkasan Hasil Uji Hipotesis

\begin{tabular}{llc}
\hline No. & \multicolumn{1}{c}{ Hipotesis } & Hasil \\
\hline 1. & H1: Integrasi pemasok berpengaruh positif terhadap kinerja rantai pasokan. & Tidak terbukti \\
2. & H2: Integrasi internal berpengaruh positif terhadap kinerja rantai pasokan. & Terbukti \\
3. & H3: Integrasi pelanggan berpengaruh positif terhadap kinerja rantai pasokan. & Tidak terbukti \\
4 & H4: Berbagi informasi berpengaruh positif terhadap kinerja rantai pasokan. & Terbukti \\
5. & H5: Penundaan berpengaruh positif terhadap kinerja rantai pasokan & Tidak terbukti \\
\hline
\end{tabular}

\section{Pembahasan}

Penelitian ditujukan untuk memberikan bukti empiris pengaruh praktik-praktik rantai pasokan yaitu integrasi pemasok, integrasi internal, integrasi pelanggan, berbagi informasi dan penundaan pada kinerja rantai pasokan. Hasil penelitian menunjukkan bahwa kinerja rantai pasokan untuk konteks UKM Sektor Batik hanya dipengaruhi oleh faktor integrasi internal dan faktor berbagi informasi.

Integrasi internal merupakan kesatuan dan kepaduan berbagai proses internal bisnis sekaligus lintas fungsi yang menentukan kesuksesan dan keberlangsungan suatu usaha, dalam hal ini adalah UKM Batik. Dalam konteks UKM, kepaduan berbagai fungsi bisnis seperti desain produk batik, pengadaan bahan baku (kain, pewarna), distribusi dan penjualan menjadi keharusan untuk dilakukan. Karakteristik produksi UKM Batik umumnya mengkombinasikan dua pola produksi yaitu produksi berbasis kapasitas (made to stock) dan produksi berbasis pesanan (made to order) yang menjadi karakteristik umum di Indonesia (lihat Indarti (2010)). Keadaan ini menjadi salah satu penjelas mengapa integrasi internal menentukan kinerja rantai pasokan. Penelitian ini sejalan dengan temuan-temuan sebelumnya dalam konteks berbeda seperti di Spanyol (Gimenez dan Ventura, 2003) dan di Amerika Serikat (Stank et al., 1999). Selain itu, temuan ini mendukung 
penelitian terdahulu lainnya seperti Narasimhan dan Kim (2002), Droge et al. (2004) dan Flynn et al. (2010).

Faktor yang menentukan kinerja rantai pasokan UKM Batik adalah berbagi informasi. Secara umum, UKM di Indonesia (seperti sektor batik, furnitur, kerajinan) tergolong dalam kategori usaha kecil dan menengah dengan jumlah tenaga kerja kurang dari 19 orang (Lihat Tabel 4). Dengan kondisi ini, pemilik dan manajemen perusahaan memiliki peran sentral (Indarti, 2010) dalam aspek berbagi informasi dalam organisasi. Kinerja perusahaan dipengaruhi oleh kemampuan pemilik dan manajemen perusahaan untuk mengelola informasi ini. Praktik ini dapat membuat perusahaan lebih responsif dalam mengakomodasi berbagai perubahan termasuk fluktuasi permintaan, masalah operasional, masalah pasokan, dan peluang pasar baru. Temuan penelitian ini konsisten dengan penelitian sebelumnya yang dilakukan oleh Li et al. (2006), Cook et al. (2011), dan Ibrahim dan Ogunyemi (2012) menemukan bahwa berbagi informasi berpengaruh positif terhadap kinerja rantai pasokan.

Penelitian ini tidak berhasil membuktikan bahwa integrasi pemasok (Hipotesis 1) dan integrasi pelanggan (Hipotesis 3) berpengaruh terhadap kinerja rantai pasokan dalam konteks perusahaan batik di Surakarta, Indonesia. Hal ini bertentangan dengan berbagai penelitian yang dilakukan sebelumnya, misalnya oleh Gimenez dan Ventura (2003; 2005); Li et al. (2006); Sundram et al. (2011); Ibrahim dan Ogunyemi (2012); Seo et al. (2014); Pamela dan Pietro (2011). Kedua integrasi ini dalam Gimenez dan Ventura (2005), merupakan komponen integrasi eksternal yang menggambarkan hubungan antarorganisasi.

Temuan ini memerlukan penjelas. Kedua integrasi ini sangat tinggi (lihat Tabel 5) namun belum memiliki dampak terhadap kinerja. Hal ini mungkin dikarenakan dampak kedua integrasi ini tidak secara langsung terjadi pada kinerja rantai pasokan, karena tidak merupakan faktor distingtif antarperusahaan yang semuanya memiliki kinerja tinggi dengan variasi yang sangat rendah. Kemungkinan penjelas lain adalah dampak kedua integrasi dimediasi oleh faktor lain yang tidak dimasukkan dalam penelitian ini. Penelitian selanjutnya dapat mencurahkan perhatian untuk secara sistematis menemukan faktor ini. Penelitian yang dilakukan oleh Gimenez, van der Vaart, dan van Donk (2012) mengindikasikan bahwa pengaruh integrasi pada kinerja tidak bersifat langsung, tetapi dimoderasi faktor lain, yaitu kompleksitas rantai pasokan. Ketika kompleksitas rantai pasokan tinggi, maka pengaruh integrasi pada kinerja tinggi, tetapi pengaruh tersebut rendah atau tidak ada jika kompleksitas rantai pasokan rendah. Yang terakhir ini adalah kasus dalam konteks UKM batik di Indonesia.

Terkait dengan pengaruh penundaan pada kinerja rantai pasokan, penelitian ini justru menemukan bahwa penundaan berpengaruh negatif. Secara konseptual, penundaan memberikan fleksibilitas kepada perusahaan untuk melakukan modifikasi produk dan perubahan fungsi permintaan (Waller et al., 2000). Mayoritas UKM di Indonesia, umumnya melakukan proses produksi berbasis pada pesanan (make-to-order) (lihat Indarti 2010), dan hal ini terjadi dalam konteks UKM Batik di Surakarta. Karakteristik proses produksi berbasis pesanan ini tidak memungkinkan perusahaan untuk melakukan banyak manuver (modifikasi) produk atau penundaan di lini produksi. Selain itu, UKM Batik memproduksi batik dengan cara tulis dan cap yang memakan waktu lama dan umumnya tidak dibuat dalam skala besar. Umumnya penundaan dilakukan pada perusahaan yang memproduksi dalam skala besar (Li et al., 2006).

\section{Simpulan}

Penelitian tentang pengaruh praktik-praktik rantai pasokan pada kinerja rantai pasokan dilakukan dengan mengambil konteks UKM Batik di Surakarta, Indonesia. Penelitian ini diharapkan memberikan kontribusi konseptual, empiris pada literatur rantai pasokan serta praktikal pada perkembangan UKM Batik. Secara konseptual dan empiris, penelitian berhasil menguatkan penelitian sebelumnya tentang pengaruh positif integrasi internal dan berbagi informasi pada kinerja rantai pasokan. Namun disisi lain, penelitian ini tidak berhasil memberikan bukti empiris terkait 
pengaruh integrasi pemasok dan integrasi pelanggan serta penundaan pada kinerja rantai pasokan. Secara praktikal, penelitian ini menegaskan pentingnya peran pemilik dan manajemen perusahaan dalam mendukung kinerja rantai pasokan. Khususnya, dalam pengelolaan internal perusahaan dan berbagi informasi.

\section{Keterbatasan dan Saran Penelitian Selanjutnya}

Penelitian ini bukan tanpa keterbatasan. Pertama, penelitian ini hanya mengambil lingkup usaha kecil dan menengah di sektor kerajinan seperti batik yang memiliki konteks spesifik, yaitu produksi berbasis pesanan. Mengambil UKM sektor lain dengan konteks yang sama dengan UKM batik seperti UKM perak dan UKM gerabah menjadi relevan dengan tujuan validasi hasil penelitian mendatang. Kedua, penelitian ini memilih pendekatan praktik rantai pasokan dan kinerjanya sebagai sebuah hal yang statis. Karenanya pengambilan data sekali waktu (cross-section) dengan survei dianggap yang paling tepat. Hanya saja, peneliti menyadari bahwa aspek dinamis yang mungkin muncul dalam praktik-praktik rantai pasokan di perusahaan dan pengaruhnya pada kinerja menjadi tidak dapat dipotret dengan baik. Lebih lanjut, kinerja memiliki karakteristik yang dinamis dan dipengaruhi oleh berbagai aspek dalam organisasi. Penelitian mendatang dapat dilakukan dengan menggunakan pendekatan waktu yang lebih lama atau longitudinal sehingga dapat menangkap dan menggali dengan lebih baik dinamika yang terjadi.

\section{Implikasi Manajerial}

Kinerja rantai pasokan dalam penelitian ini dipengaruhi oleh dua faktor, yaitu: a) integrasi internal, dan b) berbagi informasi. Karakteristik UKM yang sangat kental dengan dominansi peran pemilik/manajer, menuntut UKM untuk selalu memperhatikan dan menjaga integrasi internal dan berbagi informasi. Penting bagi UKM untuk memastikan adanya sinergi dan kepaduan antar fungsi. Hal ini dapat dilakukan dengan selalu memperhatikan intensitas berbagi informasi di dalam perusahaan.

\section{Daftar Pustaka}

Abdallah, A. B., Obeidat, B. Y., \& Aqqad, N. O. (2014). The Impact of Supply Chain Management Practices on Supply Chain Performance in Jordan: The Moderating Effect of Competitive Intensity. International Business Research, 7(3).

Barney, J. B., \& Hesterly, W. S. (2008). Strategic management and Competitive Advantage, 2rd ed. Upper Saddle River, New Jersey: Pearson Prentice Hall.

Beamon, B. M. (1999). Measuring Supply Chain Performance. International Journal of Operations \& Production Management, 19(3), 275-292.

Bernardin, H. J., \& Russel, J. E. A. (2010). Human Resource Management: An Experiential Approach, 6th ed. New York: McGraw-Hill.

Boone, C. A., Craighead, C. W., \& Hanna, J. B. (2007). Postponement: An Evolving Supply Chain Concept. International Journal of Physical Distribution \& Logistics Management, 37(8), 594-611.

Bratic, D. (2011). Achieving Competitive Advantage by Supply Chain Management. IBIMA Business Review, 2011.

Chen, I. J. \& Paulraj, A. (2004). Understanding Supply Chain Management: Critical Research and a Theoretical Framework. International Journal of Production Research, 42(1), 131-163.

Chopra, S. \& Meindl, P. (2013). Supply Chain Management: Strategy, Planning, and Operations, 5rd ed. New Jersey: Prentice-Hall. 
Chow, W. S., Madu, C. N., Kuei, C., Lu, M. H., Lin, C. \& Tseng, H. (2008). Supply Chain Management in The US and Taiwan: an Empirical Study. Omega, 36(5), 565-579.

Cook, L. S., Heiser, D. R., \& Sengupta, K. (2011). The Moderating Effect of Supply Chain Role on The Relationship Between Supply Chain Practices and Performance. International Journal of Physical Distribution \& Logistics Management, 41(2), 104-134.

Droge, C., Jayaram, J., \& Vickery, S. K. (2004). The Effect of Internal versus External Integration Practices on Time-Based Performance and Overall Firm Performance. Journal of Operations Management, 22, 557-573.

Ellinger, A. E. (2000). Improving Marketing/Logistics Cross Functional Collaboration in the Supply Chain. Industrial Marketing Management, 29, 85-96.

Flynn, B. B., Huo, B., \& Zhao, X. (2010). The Impact of Supply Chain Integration on Performance: A Contingency and Configuration Approach. Journal of Operations Management, 28(1), 5871.

Gimenez, C., \& Ventura, E. (2003). Supply Chain Management As a Competitive Advantage in The Spanish Grocery Sector, International Journal of Logistics Management, 14(1), 77-88.

Gimenez, C., \& Ventura, E. (2005). Logistics-production, Logistics-marketing and External Integration: Their Impact on Performance, International Journal of Operations \& Production Management, 25(1), 20-38.

Gimenez, C., var den Vaart, T., \& van Donk, D. P. (2012). Supply Chain Integration and Performance: the Moderating Effect of Supply Complexity, International Journal of Operations \& Production Management, 32(5), 583-610.

Gorane S. J., \& Kant, R. (2015). Supply Chain Practices. International Journal of Productivity and Performance Management, 64(5), 657-685.

Gunasekaran, A., Patel, C., \& McGaughey, R. E. (2004). A Framework for Supply Chain Performance Measurement, International Journal of Production Economics, 87(3), 333-347.

Hausman, W. H. (2002). Supply Chain Performance Metrics, Stanford University.

Heizer, J., \& Render, B. (2014). Operations Management: Sustainability and Supply Chain Management, 11th ed. England: Person Education.

Huo, B. (2012). The Impact of Supply Chain Integration on Company Performance: An Organizational Capability Perspective. Supply Chain Management: An International Journal, 17(6), 596-610.

Ibrahim, S. E., \& Ogunyemi, O. (2012). The Effect of Linkages and Information Sharing on Supply Chain and Export Performance: An Empirical Study of Egyptian Textile Manufacturers. Journal of Manufacturing Technology Management, 23(4), 441-463.

Indarti, N. (2010). The Effect of Knowledge Stickiness and Interaction on Absorptive Capacity: Evidence from furniture and software Small and Medium Enterprises in Indonesia. Dissertation. Groningen: University of Groningen.

Jabbour, A. B. L., Filho, A. G. A., Viana, A. B. N., \& Jabbour, C. J. C. (2011). Measuring Supply Chain Management Practices. Measuring Business Excellence, 15(2), 18-31.

Jean, B. R. J., Sinkovics, R. R. \& Kim, D. (2008). Information Technology and Organizational Performance within International Business to Business Relationships: A Review and An Integrated Conceptual Framework. International Marketing Review, 25(5), 563-583. 
Jeong, J. S., \& Hong, P. (2007). Customer Orientation and Performance Outcomes in Supply Chain Management. Journal of Enterprise Information Management, 20(5), 578-594.

Kahn, K. B., \& Mentzer, J. T. (1996). Logistics and Interdepartmental Integration. International Journal of Physical Distribution \& Logistics Management, 26(8), 6-14.

Lai, K. H., Ngai, E. W. T., \& Cheng, T. C. E. (2002). Measures for Evaluating Supply Chain Performance in Transport Logistics. Transportation Research Part E: Logistics and Transportation Review, 38(6), 439-456.

Lee, C. W., Kwon, I. G., \& Severance, D. (2007). Relationship Between Supply Chain Performance and Degree of Linkage Among Supplier, Internal Integration, and Customer. Supply Chain Management: An International Journal, 12(6), 444-452.

Li, S. \& Lin, B. (2006). Accesing Information Sharing and Information Quality in Supply Chain Management. Decision Support Systems, 42, 1641-1656.

Li, S., Ragu-Nathan, B., Ragu-Nathan, T. S., \& Subba Rao, S. (2006). The Impact of Supply Chain Management Practices on Competitive Advantage and Organizational Performance. Omega, 34 No. 2), 107-124.

Mentzer, J. T., Keebler, J. S., Dewitt, W., Min, S., Nix, N. W., Smith, C. D., \& Zacharia, Z. G. (2001). Defining Supply Chain Management. Journal of Business Logistics, 22(2), 1-25.

Moberg, C. R., Cutler, B. D., Gross, A. \& Speh, T. W. (2002). Identifying Antecedents of Information Exchange Within Supply Chains. International Journal of Physical Distribution \& Logistics Management, 32(9), 755-770.

Narasimhan, R. \& Kim, S. W. (2002). Effect of Supply Chain Integration on The Relationship Between Diversification and Performance: Evidence From Japanese and Korean Firms. Journal of Operations Management, 20, 303-323.

Neely, A., Richards, H., Mills, J., Platts, K. \& Bourne, M. (1997). Design Performance Measures: A Structured Approach. International Journal of Operations \& Production Management, 17(11), 31-52.

Ou, C. S., Liu, F. C., Hung, Y. C. \& Yen, D. C. (2010). A structural model of supply chain management on firm performance. International Journal of Operations and Production Management, 30(5), 526-545.

Pagell, M. (2004). Understanding the Factors that Enable and Inhibit the Integration of Operations, Purchasing and Logistics. Journal of Operations Management, 22, 459-487.

Pamela, D. \& Pietro R. (2011). Supply Chain Integration and Efficiency Performance: A Study on The Interactions Between Customer and Supplier Integration. Supply Chain Management: An International Journal, 16(4), 220-230.

Raisinghani, M. S. \& Meade, L. L. (2005). Strategic Decisions in Supply Chain Intelligence Using Knowledge Management: An Analytic-Network-Process Framework. Supply Chain Management: An International Journal, 10 No. 2), 114-121.

Robb, D. J., Xie, B. \& Arthanari, T. (2008). Supply Chain and Operations Practice and Performance in Chinese Furniture Manufacturing. International Journal of Production Economics, 112), 683-699.

Russel, R. S. \& Taylor III, B. W. (2011). Operations Management, 7th ed. New Jersey: John Wiley \& Sons.

Sarwoto. (2015). Pengaruh Fleksibilitas Manufaktur pada Kinerja: Studi Komparasi pada Perusahaan Batik dan Mebel di Surakarta. Jurnal Bisnis dan Manajemen, 15(2). 
Sekaran, U. \& Bougie, R. (2013). Research Methods for Business: a skill-building approach, $6^{\text {th }}$ ed. New Jersey: John Wiley \& Sons.

Seo, Y. J., Dinwoodie, J., \& Kwak, D. W. (2014). The Impact of Innovativeness on Supply Chain Performance: Is Supply Chain Integration a Missing Link?. Supply Chain Management: An International Journal, 19(5/6), 733-746.

Sezen, B. (2008). Relative Effects of Design, Integration and Information Sharing on Supply Chain Performance. Supply Chain Management: An International Journal, 13(3), 233-240.

Sillanpää, I. (2015). Empirical Study of Measuring Supply Chain Performance. Benchmarking: An International Journal, 22(2), 290-308.

Sundram, V. P. K., Ibrahim, A. R., \& Govindaraju, V. G. R. C. (2011). Supply Chain Management Practices in the Electronics Industry in Malaysia. Benchmarking: An International Journal, 18(6), 834-855.

Tan, K. C., Kannan, V. J., \& Handheld, R. B. (1998). Supply Chain Management: Supplier Performance and Firm Performance. International Journal of Purchasing and Materials Management, 34(3), 2-9.

Tan, K. C., Lyman, S. B., \& Wisner, J. D. (2002). Supply Chain Management: a Strategic Perspective. International Journal of Operations \& Production Management, 22(6), 614631.

Van Hoek, R. I. (2001). The Rediscovery of Postponement a Literature Review and Directions for Research. Journal of Operations Management, 19(2), 161-184.

Van Hoek, R. I., Vos, B., \& Commandeur, H. R. (1999). Restructuring European Supply Chains by Implementing Postponement Strategies. Long Range Planning, 32(5), 505-518.

Vanichchinchai, A. \& Igel, B. (2009). Total Quality Management and Supply Chain Management: Similarities and Differences. The TQM Journal, 21(3), 249-260.

Waller, M. A., Dabholkar, P. A., \& Gentry, J. J. (2000). Postponement, Product Customization, and Market-Oriented Supply Chain Management. Journal of Business Logistics, 21(2).

Wong, C. Y., Boon-itt, S. \& Wong, C. W. Y. (2011). The Contingency Effects of Environmental Uncertainty on The Relationship between Supply Chain Integration and Operational Performance, Journal of Operations Management, 29(6), 604-615.

Yang, B., Burns, B., \& Backhouse, C. (2005). An Empirical Investigation into the Barriers to Postponement. International Journal of Production Research, 43(5), 991-1005.

Yang, B., Yang, Y., \& Wijngaard, J. (2007). Postponement: an Inter-organizational Perspective. International Journal of Production Research, 45(4), 971-988.

Yang, B., Yang, Y., \& Williams, S. (2010). Service Postponement: Translating Manufacturing Postponement to Service Operations. Journal of Manufacturing Technology Management, 21(4), 470-483.

Zelbst, P. J., Green, K. W. Jr, Sower, V. E. \& Reyes, P. (2009). Impact of Supply Chain Linkages on Supply Chain Performance. Industrial Management \& Data Systems, 109(5), 665-682.

Zhao, X., Xie, J., \& Zhang, W. J. (2002). The Impact of Information Sharing and Ordering Coordination on Supply Chain Performance. Supply Chain Management: An International Journal, 7(1), 24-40.

Zhou H. \& Benton, W. C. Jr. (2007). Supply Chain Practice and Information Sharing. Journal of Operations Management, 25, 1348-1365. 